\title{
Avoidable mortality and life expectancy in New Zealand
}

\author{
M Malcolm
}

The effect of avoidable mortality on the life expectancy of Maori and non-Maori New Zealanders has been examined using a method similar to that of Benavides et $a l^{1}$ for the Valencia region of Spain. Deaths that are avoidable by primary and secondary prevention are considered separately and the potential number of years of life gained by their prevention is compared.

Methods: Sex specific abridged life tables were constructed for the Maori and non-Maori populations using data from the Departments of Health and Statistics. Further tables were then constructed with: (1) primary avoidable, (2) secondary avoidable, and (3) all avoidable deaths omitted from the numerator of the age specific mortality rates.

Primary avoidable deaths ${ }^{2}$ (at the specified ages) were: lung cancer (5-64); liver cirrhosis (15-74); and motor vehicle accidents. Secondary avoidable deaths ${ }^{2}$ were: respiratory diseases, measles (1-14); whooping cough (0-14); tuberculosis, Hodgkin's disease, appendicitis, hernia, cholelithiasis and cholecystitis, typhoid (5-64); cervical cancer (15-64); chronic rheumatic heart disease, asthma (5-44); tetanus (0-64); osteomyelitis, hypertensive and cerebrovascular diseases (35-64); perinatal and maternal deaths.

Potential gains in life expectancy are expressed as years of life gained (YLG) and as a percentage of the sex and race specific "true" life expectancy - that is, that calculated with all causes of death included. As in Benavides et $a l,{ }^{1}$ competitive mortality is not accounted for, but it is assumed that people who do not die if avoidable deaths are prevented will not die at the same age from other causes.

ESR Communicable Disease Centre, PO Box 50-348, Porirua, New Zealand M Malcolm

Correspondence to: Dr M Malcolm.

Accepted for publication January 1994

Results: Table 2 shows the main results. The difference between males and females in the relative importance of primary and secondary prevention is a result of the greater male mortality from motor vehicle accidents. Life tables constructed with these deaths not included in

Life expectancy at birth ( $L E B$ ) and years of life gained (YLG) before and after excluding avoidable deaths, New Zealand 1985-87

\begin{tabular}{|c|c|c|c|c|c|c|}
\hline & $\begin{array}{l}L E B(\text { mean } \\
(S E M))\end{array}$ & $Y L G$ & $\stackrel{\%}{\text { Gain }}$ & $\begin{array}{l}L E B \text { (mean } \\
(S E M))\end{array}$ & $Y L G$ & $\begin{array}{l}\% \\
\text { Gain }\end{array}$ \\
\hline $\begin{array}{l}\text { All deaths } \\
\text { Primary preventable excluded } \\
\text { Secondary preventable excluded } \\
\text { All preventable excluded }\end{array}$ & $\begin{array}{l}\text { Maori male } \\
67 \cdot 99(0 \cdot 25) \\
69 \cdot 41(0 \cdot 25) \\
69 \cdot 14(0 \cdot 25) \\
70 \cdot 61(0 \cdot 25) \\
\text { Maori female }\end{array}$ & $\begin{array}{l}1.42 \\
1.15 \\
2 \cdot 62\end{array}$ & $\begin{array}{l}2.09 \\
1.69 \\
3.85\end{array}$ & $\begin{array}{l}\text { Non-Maori male } \\
71.34(0.06) \\
72.62(0.06) \\
72.34(0.06) \\
73.65(0.06) \\
\text { Non-Maori female }\end{array}$ & $\begin{array}{l}1 \cdot 28 \\
1 \cdot 00 \\
2 \cdot 31 \\
l e\end{array}$ & $\begin{array}{l}1.79 \\
1.40 \\
3.24\end{array}$ \\
\hline $\begin{array}{l}\text { All deaths } \\
\text { Primary preventable excluded } \\
\text { Secondary preventable excluded } \\
\text { All preventable excluded }\end{array}$ & $\begin{array}{l}73.36(0 \cdot 30) \\
74.26(0 \cdot 30) \\
75 \cdot 10(0 \cdot 30) \\
76.04(0.30)\end{array}$ & $\begin{array}{l}0.90 \\
1.74 \\
2.68\end{array}$ & $\begin{array}{l}1.23 \\
2 \cdot 37 \\
3 \cdot 65\end{array}$ & $\begin{array}{l}77.44(0.06) \\
78.07(0.06) \\
78.48(0.06) \\
79.12(0.05)\end{array}$ & $\begin{array}{l}0.63 \\
1.04 \\
1.68\end{array}$ & $\begin{array}{l}0.81 \\
1.34 \\
2 \cdot 17\end{array}$ \\
\hline
\end{tabular}

the primary prevention group produce a male/ female pattern of YLG by primary prevention that is similar to that for secondary prevention.

Tables constructed without perinatal mortality in the secondary preventable group of causes of death (to enable comparison with Benavides et $a^{1}$ ) show that this group is similarly dominated by the perinatal deaths. Excluding perinatal mortality, YLG by secondary prevention would be 0.3 for nonMaori males and 0.42 for non-Maori females, compared with 0.38 and 0.34 for males and females respectively in Valencia. For primary preventable causes YLG in Valencia were 1.59 and 0.46 , compared with 1.28 and 0.63 for (non-Maori) males and females respectively.

Discussion: The accuracy of Maori mortality statistics is known to be questionable. ${ }^{3} \mathrm{~A}$ study of mortality from coronary heart disease ${ }^{4}$ found that official statistics underestimated Maori mortality by $82 \%$ and overestimated nonMaori mortality by $5 \%$. Similar underestimation is likely to occur for other causes of death. This study therefore almost certainly underestimates both the potential gain in life expectancy for Maori, and the difference between Maori and non-Maori avoidable mortality. Maori need to be included in any attempts to reduce this ethnic disparity, especially with regard to secondary avoidable mortality where issues of cultural appropriateness and sensitivity of health services must be addressed.

In New Zealand less than $3 \%$ of health spending was devoted to public health services in $1992 . .^{5}$ If this spending were to be increased or allocated differently, this study suggests that a substantial further benefit could be gained from primary prevention by public health measures. However, the fact that the primary avoidable deaths are dominated by motor vehicle accidents means preventive programmes with the greatest potential gains may be funded from outside the health budget.

My thanks to the Government Statistician for providing population data and information regarding life tables, and to the Director-General of Health for permission to publish.

1 Benavides FG, Orts R, Perez S. Adding years to life: effect of avoidable mortality on life expectancy at birth. $\mathcal{F}$ Epidemiol Community Health 1992;46:394-5.

2 Holland WW, ed. European Community atlas of avoidable death. Oxford: Oxford University Press, 1988

3 Graham P, Jackson R, Beaglehole R, de Boer G. The validity of Maori mortality statistics. NZ Med F 1989;102:124-6.

4 Tipene-Leach D, Stewart A, Beaglehole R. Coronary heart disease mortality in Auckland Maori and Europeans. NZ Med F 1991;104:55-6.

5 McKendry CG, Muthumala D. Health expenditure trends in New Zealand 1980-1992. Wellington: Department of Health, 1993. 